\title{
Implementing
}

PLAN COLOMBIA

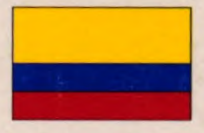

STACKS

HV

5825

M36

2001

\section{Special Series}

U.S. SECURITY POLICY

IN THE WESTERN HEMISPHERE:

Why Colombia, Why Now,

and What Is To Be Done?

Max B. Manwaring

Strategic Studies Institute SS

North-South Center

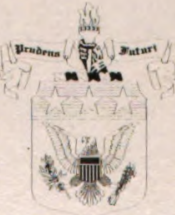

U.S. Army War College 